\title{
Immunohistochemical phenotyping of T cells, granulocytes, and phagocytes in the muscle of cancer patients: association with radiologically defined muscle mass and gene expression
}

Ana Anoveros-Barrera ${ }^{1}$, Amritpal S. Bhullar ${ }^{1}$, Cynthia Stretch², Abha R. Dunichand-Hoedl ${ }^{1}$, Karen J. B. Martins ${ }^{1}$, Aja Rieger ${ }^{3}$, David Bigam ${ }^{4}$, Todd McMullen ${ }^{4}$, Oliver F. Bathe ${ }^{5}$, Charles T. Putman ${ }^{6}$, Catherine J. Field ${ }^{1}$, Vickie E. Baracos ${ }^{7}$ and Vera C. Mazurak ${ }^{1 *}$ (1)

\begin{abstract}
Background: Inflammation is a recognized contributor to muscle wasting. Research in injury and myopathy suggests that interactions between the skeletal muscle and immune cells confer a pro-inflammatory environment that influences muscle loss through several mechanisms; however, this has not been explored in the cancer setting. This study investigated the local immune environment of the muscle by identifying the phenotype of immune cell populations in the muscle and their relationship to muscle mass in cancer patients.
\end{abstract}

Methods: Intraoperative muscle biopsies were collected from cancer patients ( $n=30,91 \%$ gastrointestinal malignancies). Muscle mass was assessed histologically (muscle fiber cross-sectional area, $\mathrm{CSA} ; \mu^{2}{ }^{2}$ ) and radiologically (lumbar skeletal muscle index, SMl; $\mathrm{cm}^{2} / \mathrm{m}^{2}$ by computed tomography, CT). T cells (CD4 and CD8) and granulocytes/phagocytes (CD11b, CD14, and CD15) were assessed by immunohistochemistry. Microarray analysis was conducted in the muscle of a second cancer patient cohort.

Results: $T$ cells (CD3+), granulocytes/phagocytes (CD11b+), and CD3-CD4+ cells were identified. Muscle fiber CSA $\left(\mu \mathrm{m}^{2}\right)$ was positively correlated (Spearman's $r=>0.45 ; p=<0.05$ ) with the total number of T cells, CD4, and CD8 T cells and granulocytes/phagocytes. In addition, patients with the smallest SMI exhibited fewer CD8 T cells within their muscle. Consistent with this, further exploration with gene correlation analyses suggests that the presence of CD8 T cells is negatively associated (Pearson's $r=\geq 0.5 ; p=<0.0001$ ) with key genes within muscle catabolic pathways for signaling (ACVR2B), ubiquitin proteasome (FOXO4, TRIM63, FBXO32, MUL1, UBC, UBB, UBE2L3), and apoptosis/autophagy (CASP8, BECN1, ATG13, SIVA1).

(Continued on next page)

\footnotetext{
* Correspondence: vmazurak@ualberta.ca

${ }^{1}$ Department of Agricultural, Food \& Nutritional Science, Faculty of

Agricultural, Life and Environmental Sciences, University of Alberta, 4-002 Li

Ka Shing Centre, Edmonton, Alberta T6G 2P5, Canada

Full list of author information is available at the end of the article
}

(c) The Author(s). 2019 Open Access This article is distributed under the terms of the Creative Commons Attribution 4.0 International License (http://creativecommons.org/licenses/by/4.0/), which permits unrestricted use, distribution, and reproduction in any medium, provided you give appropriate credit to the original author(s) and the source, provide a link to the Creative Commons license, and indicate if changes were made. The Creative Commons Public Domain Dedication waiver (http://creativecommons.org/publicdomain/zero/1.0/) applies to the data made available in this article, unless otherwise stated. 


\begin{abstract}
(Continued from previous page)
Conclusion: The skeletal muscle immune environment of cancer patients is comprised of immune cell populations from the adaptive and innate immunity. Correlations of T cells, granulocyte/phagocytes, and CD3-CD4+ cells with muscle mass measurements indicate a positive relationship between immune cell numbers and muscle mass status in cancer patients. Further exploration with gene correlation analyses suggests that the presence of CD8 T cells is negatively correlated with components of muscle catabolism.
\end{abstract}

Keywords: Muscle biopsy, Muscle mass, Muscle catabolism, Computed tomography, T cells, CD8 T cells, Granulocytes, Phagocytes, Innate immunity, Adaptive immunity, Cancer

\section{Background}

Systemic inflammation is a recognized contributor to muscle wasting in cancer. Pro-inflammatory mediators secreted by the tumor microenvironment and host responsive tissues (i.e., adipose tissue) can activate circulating and tissue-resident immune cells [1]. In the skeletal muscle tissue, interactions between the muscle and immune cells can confer an inflammatory environment promoting muscle loss through various mechanisms. For instance, pro-inflammatory cytokines such as tumor necrosis factor (TNF) alpha and interleukin (IL)-6, secreted by innate (e.g., phagocytes and granulocytes) and adaptive (e.g., T cells) immune cells, can stimulate muscle catabolism by activating nuclear factor kappa-B (NFkB) [1, 2]. Studies in experimental models report that these inflammatory cytokines can also inhibit anabolic hormones resulting in the impairment of protein synthesis [3]. The integrity of muscle fibers can be compromised by the direct cytotoxic effect of $\mathrm{T}$ cells, as observed in muscle inflammatory diseases (e.g., polymyositis and dermatomyositis) in humans $[4,5]$.

The immune cell presence has been identified with $\mathrm{CD} 45$, a general leukocyte marker, in the muscle of patients with early-stage colorectal cancer [6]; however, further characterization and quantification has never been performed in the cancer population. Innate immune cells profiled as neutrophils and macrophages with single immune markers such as CD11b or CD15 or CD14 have been identified in the muscle tissue of populations with myopathy (polymyositis and dermatomyositis), obesity, and exercise-induce stress [7-10]. The presence of $\mathrm{T}$ cells within the muscle tissue is commonly explored using CD3 with or without CD4 or CD8 in patients with myopathy and healthy adults undergoing eccentric exercise [7-9, 11, 12].

Exploration of the skeletal muscle immune environment is emerging in human muscle biopsies, which will enable a better understanding of the immune components that contribute to cancer-associated muscle wasting. Also, secondary analysis of oncologic images has enabled the precise characterization of muscle mass distribution in the cancer populations from which these biopsies are derived [13]. Comparison of cancer patients with and without muscle wasting is providing new mechanistic insights into muscle loss [14, 15].

Therefore, in this study, we aimed to investigate the skeletal muscle immune-environment by exploring the presence of different immune cell populations and their relationship to muscle mass in cancer patients undergoing abdominal surgery. It was hypothesized that cancer patients with lower muscle mass have more phagocytes/ granulocytes (CD11b, CD15, and CD14) and T cells (CD3, CD4, and CD8) within their muscle tissue.

\section{Methods \\ Study population}

Thirty cancer patients undergoing elective abdominal surgery for purposes of cancer diagnosis, primary treatment, or liver metastasis removal were consecutively approached to participate. Previous history of muscle inflammatory disease (i.e., polymyositis, dermatomyositis, and inclusion body myositis) was considered as exclusion criteria. Subject demographics and clinical information were extracted from clinical charts. The majority of patients included in the study were in naïve to chemotherapy and radiotherapy $(n=23)$. Three patients had chemotherapy 9 months prior to the biopsy. Three patients had chemotherapy 1 month prior to the biopsy. One patient received chemotherapy and radiotherapy 4 months prior to the biopsy.

\section{Radiological assessment of muscle mass by $\mathrm{CT}$ scan}

Pre-operative CT scans performed as the standard of care in the cancer were used to quantify skeletal muscle L3-CSA $[16,17]$. Briefly, CT images collected at the 3rd lumbar vertebrae (L3) were analyzed with Slice-O-Matic ${ }^{\circ}$ V4.3 (Tomovision, Montreal, QB, Canada), L3 muscle CSA was identified at a range of -29 to +150 Hounsfield units (HU). Skeletal muscle index (SMI) was obtained by adjusting muscle CSA for height $\left(\mathrm{cm}^{2} / \mathrm{m}^{2}\right)$. These pre-operative CT images document the inclusion of male and female patients representing the entire SMI distribution of the population being sampled $(n=1473)$ from our regional cancer center in Alberta, Canada (Fig. 1) [18]. SMI $z$-scores for each subject were calculated based on sex and decade of 


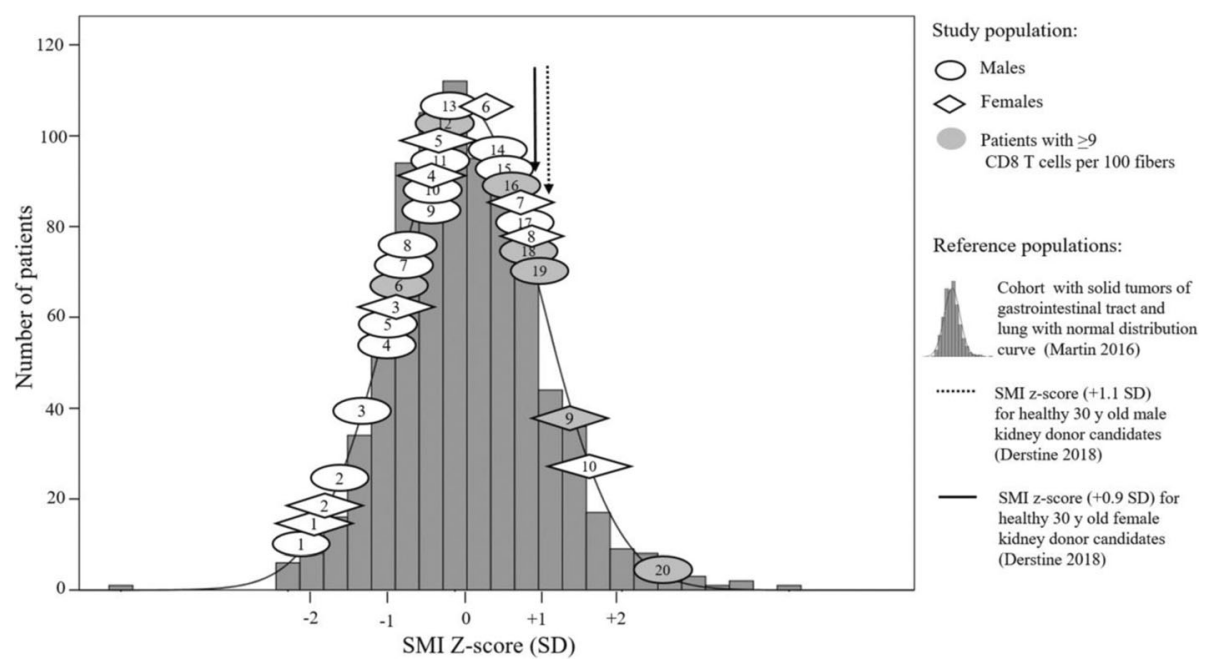

Fig. 1 SMI $z$-scores (SD, standard deviation) for male ( $n=20$, circles) and female ( $n=10$, diamonds) patients of the current study in relation to the SMI $z$-score distribution (dark gray histogram) from a cancer cohort with gastrointestinal tract and lung solid tumors $(n=1473,58 \%$ males) from the same regional cancer center [13]. SMl z-scores were calculated based on sex and age [15]. Circle and diamonds in light gray are patients with highest values of CD8 T cells per 100 fibers. Vertical arrows representing SMI z-scores (SD) for healthy 30-year-old kidney donor candidates were placed to highlight cancer patient with SMI Z-score values that are similar to the healthy population [61]. Notes: Only one SMI distribution is shown indistinctively of sex, as male $(n=828)$ and female $(n=645)$ SMI distribution shapes were the same in the Martin et al. cohort [13]. SMI $z-$ scores for healthy kidney donor candidates were calculated by subtracting Martin et al. oncological cohort mean SMI values (males: $51.5 \mathrm{~cm}^{2} / \mathrm{m}^{2} /$ females: $41.3 \mathrm{~cm}^{2} / \mathrm{m}^{2}$ ) from Derstine et al. healthy 30-year-old mean SMI values (males: $60.9 \mathrm{~cm}^{2} / \mathrm{m}^{2} /$ females: $47.5 \mathrm{~cm}^{2} / \mathrm{m}^{2}$ ) and divided by the SD of Martin et al. oncological cohort (males: $\pm 8.9 /$ females: \pm 7 )

age using mean values and standard deviation of the population cohort [19]. Further group comparison (low and normal muscle mass) was done based in SMI mean \pm standard deviation of 30-year-old healthy individuals [20].

\section{Muscle biopsies}

Rectus abdominis $(\approx 1 \mathrm{~g})$ was collected at the initial stage of the surgical procedure. An upper abdominal transverse incision was performed, the muscle was collected by sharp dissection without the use of electrocautery, and biopsies were placed on ice within $10 \mathrm{~min}$. On average, a period of $30 \mathrm{~min}$ occurred between biopsy removal and arrival in the laboratory. Visually evident adipose and connective tissue was removed from the muscle specimen. For morphological assessment, the tissue was frozen in cooled isopentane and stored at $-80^{\circ} \mathrm{C}$. Sample processing time after the arrival of the specimen to the laboratory was within $1.5 \mathrm{~h}$; procedures were performed under sterile conditions and tissue was kept on ice.

\section{Immunohistochemistry}

Immunofluorescence was performed in transverse serial sections of $10-\mu \mathrm{m}$ thickness cut with cryostat Leica model $\mathrm{CM} 300$ at $-22^{\circ} \mathrm{C}$. Experiments were done using three serial sections, two slides for immune cell identification [antibody combination: (1) CD3, CD4, and nuclear stain and (2) CD11b, CD14, CD15, and nuclear stain] and one slide for muscle fiber area assessment [antibody combination: (3) laminin/dystrophin]. Tissue slides (Apex ${ }^{\mathrm{Tm}}$ superior adhesive slides, Leica Biosystems) were fixed in acetone at $-20^{\circ} \mathrm{C}$, washed several times in phosphate-buffered saline (PBS), and incubated with blocking solution (PBS-Tween 20, 10\% normal goat serum and $1 \%$ bovine serum albumin) for $1 \mathrm{~h}$. Sections were washed in PBS prior to incubation with primary antibodies (Additional file 1: Table S1) at $4{ }^{\circ} \mathrm{C}$ overnight. Tissue was washed one time in PBS-Tween 20 and six times in PBS before application of secondary antibodies. Secondary antibodies (see Additional file 2: Table S2) used with CD3, CD11b, and laminin/dystrophin was Alexa Fluor 647 of goat anti-rabbit IgG, with CD4 and CD14 was Alexa Fluor 568 of goat anti-mouse IgG1, and with CD15 was Alexa Fluor 488 of goat anti-mouse IgM. After $2 \mathrm{~h}$ of secondary incubation at room temperature, sections were washed six times in PBS. Nuclear stain, 4',6-diamidino-2phenylindole (DAPI), was added for $2 \mathrm{~min}$. Slides were mounted in ProLong ${ }^{\circ}$ Diamond Antifade medium, covered with 1.5-thick coverslips and let to dry flat for $12 \mathrm{~h}$.

\section{Confocal microscopy and histological analysis}

Muscle sections were visualized with a spinning disk confocal microscope (Quorum Wave FX Spinning Disc Confocal System - Quorum technologies). Z-stacked images taken across a tissue section using the $\times 20 / 0.85$ oil lens were assembled together and plane-merged to create a composite image to enable the visualization of a whole and clear tissue cross-section. Volocity 6.3 software [PerkinElmer, Waltham, 
MA, USA] was used to capture, merge, and analyze all images.

\section{Immune cell quantification}

Immune cells located in the endomysium were quantified. Assessments were performed on a total area of $2.0 \pm 0.7$ $\mathrm{mm}^{2}$ which included information of $398 \pm 97$ muscle fibers. Manual immune cell quantification was performed using Volocity software, and results were reported as the number of cells per 100 fibers. Values were also presented as the number of cells per $\mathrm{mm}^{2}$ for comparison with other study populations reported in the literature. CD3+CD4- cells were profiled as CD8 T cells. Areas excluded for immune cell quantification were large blood vessels and detectable capillaries, nerves, fibrotic tissue, and folded areas. Immune cell populations were identified based on the co-expression of cell surface markers, and immune cells were quantified only if they had a nucleus surrounded by the fluorescent antibody on the surface (see Additional file 3: Figure S1). Endomysial areas and muscle fibers were located by increasing the brightness of the image as muscle tissue autofluorescence easily allowed the identification of muscle structures. In addition, muscle fibers and endomysium location were corroborated using serial sections of laminindystrophin stain (see Additional file 4: Figure S2).

\section{Muscle fiber CSA analysis}

Image assessment of muscle fiber CSA was done using in Volocity software. First, muscle fiber CSA $\left(\mu \mathrm{m}^{2}\right)$ was obtained from the detection of membrane fluorescence of single muscle fibers. Second, a mean muscle fiber CSA value was calculated from the area assessment of all muscle fibers per cross section.

\section{Immune cell isolation and flow cytometry analysis}

Mononuclear cells were isolated from the rectus abdominis muscle in a subset of $n=17$ (males $=12 /$ females $=5$ ) patients using similar procedures to those previously described [21]. Briefly, $150 \mathrm{mg}$ of the muscle was digested in an enzymatic solution (DMEM with collagenase 1\%, dispase II, and $\left.\mathrm{CaCl}_{2}\right)$ at $37^{\circ} \mathrm{C}\left(5 \% \mathrm{CO}_{2}\right)$. After washing, the sample was filtered through a mesh. The pellet was resuspended in PBS with 4\% FBS, and cells counted using trypan blue. Volume equivalent to one million mononuclear cells was used. Conjugated antibodies (CD3-BV421 and CD11b-PE-Cy7; BD Biosciences) for cell surface antigens were mixed in aliquot cocktails and added into the respective tubes, including fluorescence minus one controls (FMOs). Samples were incubated at $4{ }^{\circ} \mathrm{C}$ in the dark for $40 \mathrm{~min}$. After incubation, cells were washed twice and fixed with $100 \mu \mathrm{L}$ of $1 \%$ paraformaldehyde. Tubes were refrigerated for $12 \mathrm{~h}$ until flow cytometry acquisition was performed with a BD Fortessa X-20 analyzer and BD FacsDiva ${ }^{\mathrm{Tm}}$ software [BD Biosciences].
Finally, flow cytometry analyses were done using FlowJo@ software [FlowJo, LLC] (Additional file 5: Figure S3).

\section{Gene expression: microarray analysis}

Microarray analysis was conducted in the rectus abdominis muscle from a cohort of patients $(n=69$ males $/ n=64$ females) previously described [22]. Briefly, total RNA was isolated, purified, quantified, and subjected to linear amplification and Cy3 labeling and hybridization to Agilent Whole Human Genome Arrays using Agilent kits (One Color Low RNA Input Linear Amplification Kit Plus, One Color RNA Spike-In Kit and Gene Expression Hybridization Kit) according to the manufacturer's protocols. The arrays were scanned using an Agilent Scanner, the data was extracted, and quality was evaluated using Feature Extraction Software 10.5.1 (Agilent). The data were normalized using GeneSpring GX 11.5.1 (Agilent). The data used in this publication have been deposited in the US National Center for Biotechnology Information (NCBI) Gene Expression Omnibus25 and are accessible through GEO series accession number GSE41726.

\section{Statistical analysis}

All analyses were conducted in $\mathrm{IBM}^{\circ} \mathrm{SPSS}^{\circ}$ Statistics software, version 24. A test for normal distribution was applied to the continuous variables, and immune cells were not normally distributed. To assess associations between immune cells and muscle mass values, Spearman's coefficient was selected. Comparisons between sexes and groups were conducted using Mann-Whitney $U$ (noncategorical variable) and chi-square or Fisher's exact test (categorical variables) where appropriate. Statistical significance was considered at $p$ values less than 0.05 .

\section{Gene correlation analyses}

Pearson correlation analysis was done in $\mathrm{R}$ version 3.4.2 (2017-09-28) using the Hmisc (version 4.1-1) and corrplot (version 0.84) packages. Correlation analysis between CD8A and all other genes in the microarray was used to identify significantly correlated genes. The correlation $p$ values were adjusted for multiple comparisons using the Benjamini-Hochberg procedure. Correlations were considered significant if they had a false discovery rate (FDR) of $<0.05$. Of those genes significantly correlated with CD8A, genes associated with CD8 T cell function and muscle catabolism were identified based on a review of the current literature and submitted to further analysis. Correlations between all gene-gene combinations were conducted to examine the relationship between CD8 T cell genes and catabolic genes.

\section{Results}

Patient characteristics are presented in Table 1. Mean age was $64 \pm 11$ years, and there were no age differences 
Table 1 Patient characteristics

\begin{tabular}{|c|c|c|c|c|}
\hline & $\begin{array}{l}\text { All } \\
(n=30)\end{array}$ & $\begin{array}{l}\text { Males } \\
(n=20)\end{array}$ & $\begin{array}{l}\text { Females } \\
(n=10)\end{array}$ & $p$ \\
\hline $\begin{array}{l}\text { Age, mean years } \pm S D \\
\text { (Min-Max) }\end{array}$ & $\begin{array}{l}64 \pm 11 \\
(38-81)\end{array}$ & $\begin{array}{l}63 \pm 13 \\
(38-81)\end{array}$ & $\begin{array}{l}67 \pm 7 \\
(52-77)\end{array}$ & 0.71 \\
\hline Tumor type, \% (n) & & & & 0.68 \\
\hline Colorectal & $37(11)$ & $35(7)$ & $40(4)$ & \\
\hline Pancreas & $30(9)$ & $25(5)$ & $40(4)$ & \\
\hline Liver & $10(3)$ & $10(2)$ & $10(1)$ & \\
\hline Bile duct & $7(2)$ & $10(2)$ & $0(0)$ & \\
\hline Gallbladder & $7(2)$ & $5(1)$ & $10(1)$ & \\
\hline Others & $9(3)$ & $15(3)$ & $0(0)$ & \\
\hline Tumor stage, \% (n) & & & & 0.22 \\
\hline 1 & $3.3(1)$ & $5(1)$ & $0(0)$ & \\
\hline$\|$ & $3.3(1)$ & $5(1)$ & $0(0)$ & \\
\hline III & $13(4)$ & $10(2)$ & $20(2)$ & \\
\hline IV & $67(20)$ & $60(12)$ & $80(8)$ & \\
\hline N/A & $13.3(4)$ & $20(4)$ & $0(0)$ & \\
\hline BMI $\left(\mathrm{kg} / \mathrm{m}^{2}\right)$, mean $\pm \mathrm{SD}$ & $27 \pm 7$ & $27 \pm 6$ & $26 \pm 9$ & 0.68 \\
\hline BMI classification, \% (n) & & & & 0.24 \\
\hline Underweight & $10(3)$ & $10(2)$ & $10(1)$ & \\
\hline Normal & $47(14)$ & $40(8)$ & $60(6)$ & \\
\hline Overweight & $23(7)$ & 30 (6) & $10(1)$ & \\
\hline Obesity I & $7(2)$ & $5(1)$ & $10(1)$ & \\
\hline Obesity II & $10(3)$ & $15(3)$ & $0(0)$ & \\
\hline Obesity III & $3(1)$ & $0(0)$ & $10(1)$ & \\
\hline \multicolumn{5}{|l|}{ Comorbidities, \% (n) } \\
\hline Diabetes type II & $30(9)$ & $20(4)$ & $50(5)$ & 0.96 \\
\hline Hypertension & $50(15)$ & $50(5)$ & $50(5)$ & 1.00 \\
\hline CVD & $23(7)$ & $25(5)$ & $20(2)$ & 0.76 \\
\hline Dyslipidemia & $23(7)$ & $25(5)$ & $20(2)$ & 0.76 \\
\hline \multicolumn{5}{|l|}{$\begin{array}{l}\text { Computed tomography body } \\
\text { composition analysis, mean } \pm \text { SD }\end{array}$} \\
\hline L3 Muscle CSA $\left(\mathrm{cm}^{2}\right)$ & $\begin{array}{l}132.1 \pm \\
33.9\end{array}$ & $\begin{array}{l}146.8 \pm \\
29.5\end{array}$ & $\begin{array}{l}102.6 \pm \\
20.3\end{array}$ & $<0.01^{*}$ \\
\hline $\operatorname{SMI}\left(\mathrm{cm}^{2} / \mathrm{m}^{2}\right)$ & $\begin{array}{l}45.8 \pm \\
9.2\end{array}$ & $\begin{array}{l}49 \pm \\
8.5\end{array}$ & $\begin{array}{l}40.5 \pm \\
8.4^{*}\end{array}$ & 0.39 \\
\hline SMI z-score (SD) & $\begin{array}{l}-0.2 \pm \\
1.1\end{array}$ & $\begin{array}{l}-0.3 \pm \\
1.1\end{array}$ & $\begin{array}{l}-0.1 \pm \\
1.2\end{array}$ & 0.59 \\
\hline L3 Muscle radiodensity (HU) & $\begin{array}{l}30.8 \pm \\
9.5\end{array}$ & $\begin{array}{l}31.4 \pm \\
10.5\end{array}$ & $\begin{array}{l}30.4 \pm \\
7.6\end{array}$ & 0.72 \\
\hline L3 VAT CSA $\left(\mathrm{cm}^{2}\right)$ & $\begin{array}{l}172.3 \pm \\
91.9\end{array}$ & $\begin{array}{l}188 \pm \\
97.2\end{array}$ & $\begin{array}{l}150.6 \pm \\
79.7\end{array}$ & 0.29 \\
\hline L3 SAT CSA $\left(\mathrm{cm}^{2}\right)$ & $\begin{array}{l}192.8 \pm \\
115.2\end{array}$ & $\begin{array}{l}165.2 \pm \\
110.7\end{array}$ & $\begin{array}{l}247.5 \pm \\
102.2\end{array}$ & $0.015^{*}$ \\
\hline L3 TAT CSA $\left(\mathrm{cm}^{2}\right)$ & $\begin{array}{l}377.1 \pm \\
172.3\end{array}$ & $\begin{array}{l}365.2 \pm \\
173\end{array}$ & $\begin{array}{l}409.5 \pm \\
168.9\end{array}$ & 0.45 \\
\hline $\begin{array}{l}\text { Muscle histological characteristics: } \\
\text { Muscle fiber } C S A\left(\mu m^{2}\right) \text {, mean } \pm S D\end{array}$ & $\begin{array}{l}3154 \pm \\
1408\end{array}$ & $\begin{array}{l}3707 \pm \\
1329\end{array}$ & $\begin{array}{l}2047 \pm \\
788^{*}\end{array}$ & $<0.01^{*}$ \\
\hline
\end{tabular}

Others: melanoma, chronic lymphocytic leukemia, and lymphoma. N/A no applicable, BMI body mass index, CVD cardiovascular disease, L3 lumbar 3 , CSA cross-sectional area, HU Hounsfield unit, VAT visceral adipose tissue, SAT subcutaneous adipose tissue, TAT total adipose tissue, SMI skeletal muscle index, $S D$ standard deviation. *Difference between males and females $(p=<0.05)$ between men and women. Most patients had gastrointestinal malignancies (91\%), with colorectal and pancreatic cancer being common among males and females. Advance stage (IV) was present in $60 \%$ of men and $80 \%$ of women.

\section{Innate and adaptive immune cells are present in the muscle of cancer patients}

$\mathrm{T}$ cells, CD3-CD4+, and granulocytes/phagocytes were identified in the muscle tissue of patients diagnosed with cancer (Table 2 and Fig. 2). Immune cells were consistently found in the periphery of the muscle fibers, in the area known as endomysium (Fig. 2). In general, the distribution of immune cells occurred along the tissue with a clear separation between cells (Fig. 3).

$\mathrm{T}$ cells accounted for $67 \%$ of immune cells identified within the muscle tissue (Table 2). CD8 T cells (CD3+CD4-) were twice as abundant as CD4 $\mathrm{T}$ cells $(\mathrm{CD} 3+\mathrm{CD} 4+)$. A population of $\mathrm{CD} 3-\mathrm{CD} 4+$ cells was identified and represented $14 \%$ of the immune cells. CD11b+cells comprised $20 \%$ of the immune cells identified, and two subtypes of CD11b+cells were identified. CD11b+CD14+CD15+ cells were present at 1.6 fold higher than CD11b+CD14-CD15- cells. Immune cells with single antigens for CD14 or CD15 were not present. Males had more CD4 T cells than females (Table 2). No other differences between men and women were observed.

Flow cytometry analysis enabled confirmation of the immune populations explored in the immunohistochemistry assays (see Additional file 8: Figure S3). Immune cells comprised a very small percentage of isolated mononuclear cells. CD3+ cells comprised of $1.8 \pm 1 \%$ (mean \pm standard deviation) and CD11b + of $1.6 \pm 1.3 \%$ (mean \pm standard deviation). No statistical differences were found between males and females for CD3 $(p=0.2)$ or CD11b cells $(p=0.9)$. No further analyses were pursued given the low numbers of CD3+ and CD11b+ cells obtained from the muscle tissue.

\section{$T$ cells (CD3+), CD3-CD4+ cells, and granulocytes/ phagocytes (CD11b+) cells are positively correlated with muscle mass}

Muscle mass was evaluated by histological and radiological assessments (Table 1). Muscle mass measurements are reported as muscle fiber CSA, L3-CSA, SMI, and SMI $z$-scores. Correlations between immune cells and muscle mass variables are reported in Table 3 . Muscle fiber CSA was positively correlated with total $\mathrm{CD} 3+, \mathrm{CD} 4(\mathrm{CD} 3+\mathrm{CD} 4+)$ and $\mathrm{CD} 8(\mathrm{CD} 3+\mathrm{CD} 4-) \mathrm{T}$ cells, CD3-CD4+ cells, and granulocytes/phagocytes subtype $1(\mathrm{CD} 11 \mathrm{~b}+\mathrm{CD} 14+\mathrm{CD} 15+)$. SMI and SMI $z$ scores were positively correlated with total CD3+ T cells and CD8 T cells. 
Table 2 Immunohistochemical identification and quantification of immune cells in the muscle

\begin{tabular}{|c|c|c|c|c|c|}
\hline \multirow[t]{2}{*}{ Immune cell identified } & \multirow[t]{2}{*}{ Antibodies } & All $(n=30)$ & Males $(n=20)$ & \multirow[t]{2}{*}{ Females $(n=10)$} & \multirow[b]{2}{*}{$p$ value } \\
\hline & & \multicolumn{2}{|c|}{ No. of cells per 100 fibers } & & \\
\hline Granulocytes/phagocytes & CD11b+ & $1.6(0-8)$ & $1.6(0-6)$ & $1.6(1-8)$ & 0.98 \\
\hline a. Granulocytes/phagocytes subtype 1 & CD11b+CD14+CD15+ & $1.0(0-5)$ & $1.3(0-4)$ & $0.5(0-5)$ & 0.32 \\
\hline b. Granulocytes/phagocytes subtype 2 & CD11b+CD14-CD15- & $0.5(0-3)$ & $0.0(0-2)$ & $1.1(0-3)$ & 0.14 \\
\hline T cells & CD3+ & $6.5(1-24)$ & $8.3(1-24)$ & $5.5(1-12)$ & 0.07 \\
\hline a. CD4 T cells & $\mathrm{CD} 3+\mathrm{CD} 4+$ & $2.3(0-15)$ & $2.7(0-15)$ & $1.7(0-6)$ & $0.05^{*}$ \\
\hline b. CD8 T cells & $\mathrm{CD} 3+\mathrm{CD} 4-$ & $4.1(1-18)$ & $5.6(1-18)$ & $4(1-10)$ & 0.21 \\
\hline CD3-CD4+ cells & $\mathrm{CD} 3-\mathrm{CD} 4+$ & $0.6(0-12)$ & $2.0(0-6)$ & $0.7(0-12)$ & 0.71 \\
\hline
\end{tabular}

Values reported as median (range). $p$ values from Mann-Whitney $U$ test. *Difference between males and females $(p=<0.05)$

In women, significant correlations between muscle fiber CSA, CD3 $+\mathrm{T}$ cells $(r=0.8, p=0.006)$, and CD8 $(\mathrm{CD} 3+\mathrm{CD} 4-) \mathrm{T}$ cells $(r=0.9, \quad p=0.001)$ were observed. In men, muscle fiber CSA was positively correlated with total number of $\mathrm{CD} 11 \mathrm{~b}+$ cells $(r=0.5$, $p=0.01), \quad \mathrm{CD} 11 \mathrm{~b}+\mathrm{CD} 14+\mathrm{CD} 15+\quad(r=0.6, \quad p=0.007)$, total CD3+ T cells $(r=0.5, \quad p=0.01)$, and CD8 (CD3+CD4-) $\mathrm{T}$ cells $(r=0.6, p=0.01)$. In addition, CD3+ T cells were correlated with SMI $(r=0.6, p=$ $0.006)$ and SMI $z$-scores $(r=0.6, p=0.004)$; CD8 $(\mathrm{CD} 3+\mathrm{CD} 4-) \mathrm{T}$ cells to SMI $(r=0.5, p=0.004)$ and SMI $z$-scores $(r=0.6, p=0.005)$ in men.

\section{Comparison of patient characteristics based on normal} and low muscle mass

Cancer patients participating in the present study represent the entire SMI distribution reported in a population from the same region with solid gastrointestinal and respiratory tumors (Fig. 1). A subset of patients (37\%) was identified as having SMI values within what is reported for normal muscle mass in 30-year-old individuals (Table 4) [20]. Further comparison of patient characteristics between normal and low muscle mass revealed no differences in age and number of men between groups. The prevalence of patients with stage IV and chemotherapy was higher in the low muscle mass group. Patients with the highest proportions of CD8 T cells (> 9 cells per 100 fibers) were present in the normal muscle mass group (Table 4 and Fig. 1).

\section{Gene analysis: CD8 T cells negatively associated with catabolic pathways in the muscle} Microarray analyses were performed in the rectus $a b$ dominis muscle of a second cohort with similar clinical characteristics to our main cohort (see Additional file 6: Table S3) [22]. Forty-six genes were selected for this analysis representing $\mathrm{T}$ cells and

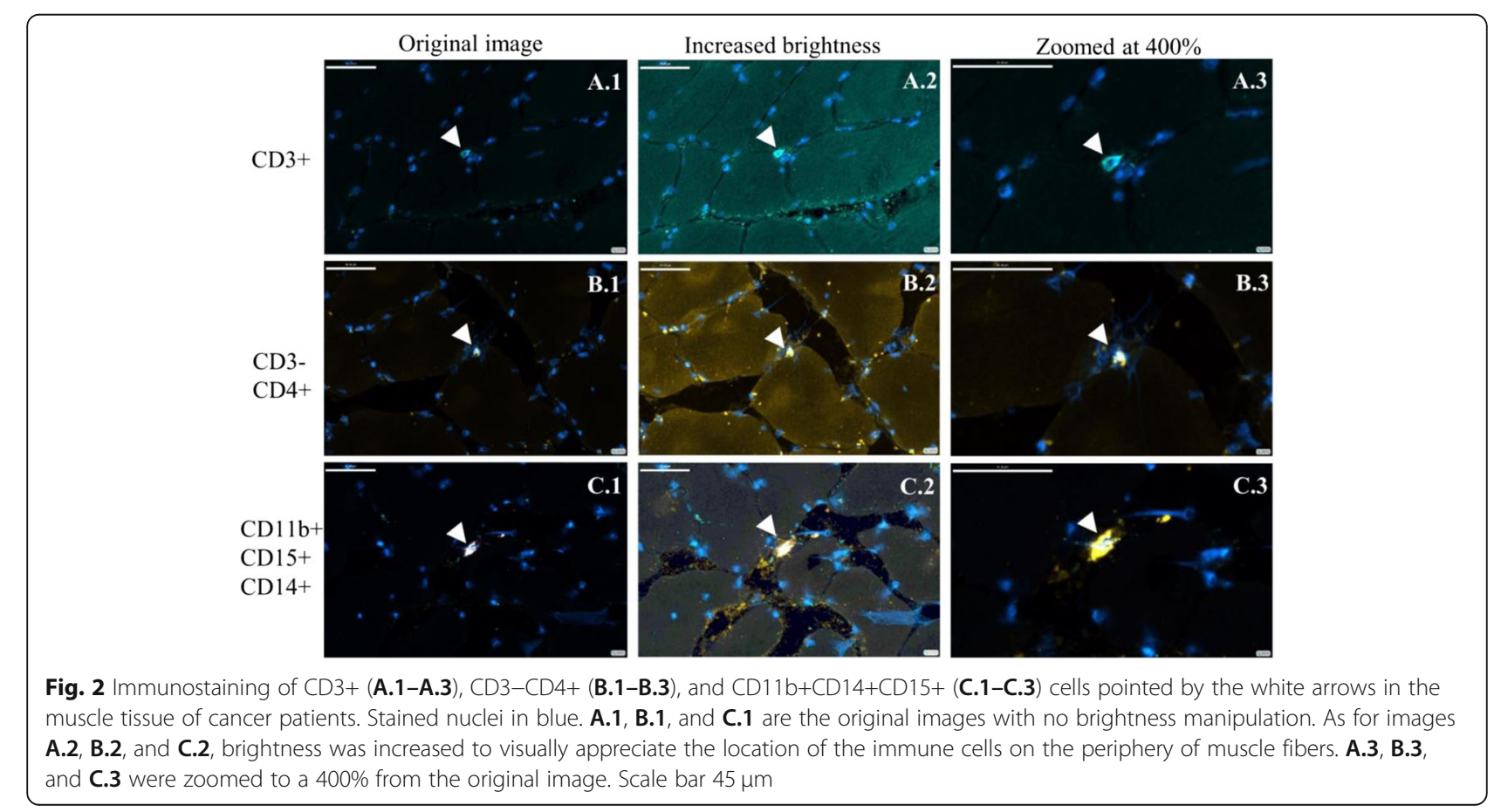




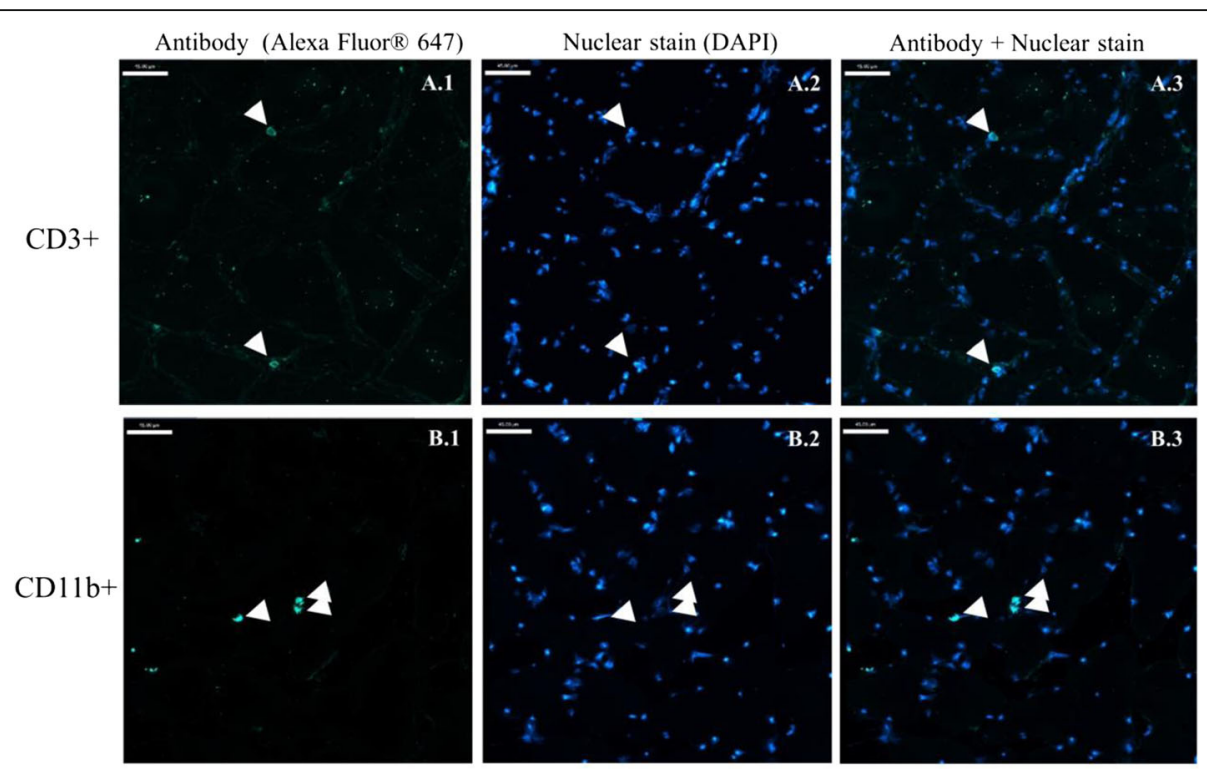

Fig. 3 Representation of the distribution of more than one immune cell localized on a muscle cross section. Immunostaining of CD3+ (A.1-A.3) and CD11b+ (B.1-B.3). A.1 and B.1 antibody detected by Alexa Fluor ${ }^{\circledR}$ 647. A.2 and B.2 nuclear stain (DAPI). A.3 and B.3 antibody and nuclear stain. Scale bar $45 \mu \mathrm{m}$

CD8 $\mathrm{T}$ cell function [23-28], as well as muscle catabolic pathways (Additional files 7 and 8: Table S4 and Table S5) $[1,2,29-38]$. The gene correlation matrix is presented in Fig. 4 for men (see Additional file 9: Figure S4 for women). CD8 $\mathrm{T}$ cell-associated genes and muscle catabolic genes were inversely correlated in both men and women (Additional files 7 and 8: Table S4 and Table S5); however, more consistent and stronger correlation coefficients were observed in men in comparison to women, as we had seen for the immune cell counts and measures of muscle mass. In men, $\mathrm{T}$ cell function and CD8 $\mathrm{T}$ cell-specific genes were negatively correlated with ubiquitin-proteasome genes (FOXO4, STUB1, UBE2R2, and USP2) and autophagy/ apoptosis genes (BECN1). Genes from the ubiquitin proteasome (TRIM63, MUL1, FBXO32, UBB, UBC, USP4, UBE2B, UBE2L3, UBA52, and DNAJC11), catabolic signaling (ACVR2B and ACVR1B), apoptosis (SIVA1), and autophagy (ATG13) pathways were negatively correlated with $\mathrm{T}$ cell function genes. Apoptotic gene CASP8 was negatively correlated with CD8 T cell-specific gene GZMA.

Further gene exploration on the correlation of CD8A gene with regulatory cytokine IL-10 and proinflammatory cytokine IL-6 was done. A significant positive correlation was found between CD8A and IL10 receptor subunit $\alpha(r=0.6, p=<0.001)$, and no significant correlations were observed for IL-10 $(r=$ $0.2, p=0.2)$, IL-6 $(r=0.2, p=0.19)$, or IL-6 receptor $(r=-0.2, p=0.07)$.

\section{Discussion}

This is the first study to investigate the local immune environment of the skeletal muscle by identifying immune cell populations in the muscle and their relationship to muscle mass in cancer patients. T cells, CD3 -CD4+ cells, and granulocytes/phagocytes were identified. Assessment of the relationship between immune

Table 3 Correlation between the number of immune cells and muscle mass variables, all patients $(n=30)$

\begin{tabular}{|c|c|c|c|c|c|c|c|c|}
\hline & & $\begin{array}{l}\text { Total T } \\
\text { cells }\end{array}$ & $\begin{array}{l}\text { CD4 T } \\
\text { cells }\end{array}$ & $\begin{array}{l}\text { CD8 T } \\
\text { cells }\end{array}$ & $\begin{array}{l}\text { CD3-CD4+ } \\
\text { cells }\end{array}$ & $\begin{array}{l}\text { Total } \\
\text { granulocytes/ } \\
\text { phagocytes }\end{array}$ & $\begin{array}{l}\text { Granulocytes/ } \\
\text { phagocytes } \\
\text { subtype } 1\end{array}$ & $\begin{array}{l}\text { Granulocytes/ } \\
\text { phagocytes } \\
\text { subtype } 2\end{array}$ \\
\hline \multirow[t]{2}{*}{ Muscle fiber CSA } & $r$ & 0.63 & 0.41 & 0.63 & 0.45 & 0.29 & 0.46 & -0.05 \\
\hline & $p$ & 0.0002 & 0.026 & 0.0002 & 0.012 & 0.126 & 0.011 & 0.784 \\
\hline \multirow[t]{2}{*}{ SMI } & $r$ & 0.49 & 0.28 & 0.44 & 0.2 & -0.003 & 0.14 & -0.16 \\
\hline & $p$ & 0.006 & 0.136 & 0.014 & 0.59 & 0.986 & 0.44 & 0.395 \\
\hline \multirow[t]{2}{*}{ SMI z-scores } & $r$ & 0.44 & 0.12 & 0.49 & 0.24 & -0.04 & 0.05 & -0.12 \\
\hline & $p$ & 0.016 & 0.517 & 0.005 & 0.186 & 0.823 & 0.782 & 0.527 \\
\hline
\end{tabular}

$r=$ Spearman's coefficient of correlation. $p=<0.05$ : statistical significance. CSA cross-sectional area, SMI skeletal muscle index 
Table 4 Comparison of characteristics of cancer patients with low muscle mass and normal muscle mass

\begin{tabular}{llll}
\hline & Normal muscle mass & Low muscle mass & $p$ value \\
\hline Total sample size, $n$ & 11 & 19 & $74(14)$ \\
Males, \% $(n)$ & $55(6)$ & $64.3 \pm 10.4$ & \\
Age, mean years \pm SD & $63.5 \pm 13$ & $44.6 \pm 5.4$ \\
SMl $\left(\mathrm{cm}^{2} / \mathrm{m}^{2}\right)$, mean \pm SD & & $33.8 \pm 5.7$ \\
Males & $59 \pm 4.9$ & $74(14)$ & $<.25$ \\
Females & $47.2 \pm 4.0$ & $37(7)$ & $<0.01$ \\
Patients with stage IV, \% $(n)$ & $55(6)$ & $11(2)$ & 0.01 \\
Patients exposed to chemotherapy, \% $(n)$ & $0(0)$ & $45(5)$ & 0.025 \\
Patients with $>9$ CD8 T cells per 100 fibers, \% $(n)$ & & 0.043 \\
\hline
\end{tabular}

Normal muscle mass: patients with SMI $\left(\mathrm{cm}^{2} / \mathrm{m}^{2}\right)$ within the mean \pm standard deviation (SD) of 30-year-old healthy individuals (males: $60.9 \pm 7.8 \mathrm{~cm} / / \mathrm{m}^{2} / / \mathrm{females:}$ $47.5+6.6 \mathrm{~cm}^{2} / \mathrm{m}^{2}$ ) as reported by Derstine et al. [20] Differences between groups were analyzed by Mann-Whitney $U$ test (non-categorical variables) and Fisher's exact test (categorical variables) where appropriate. Statistical significance $p<0.05$

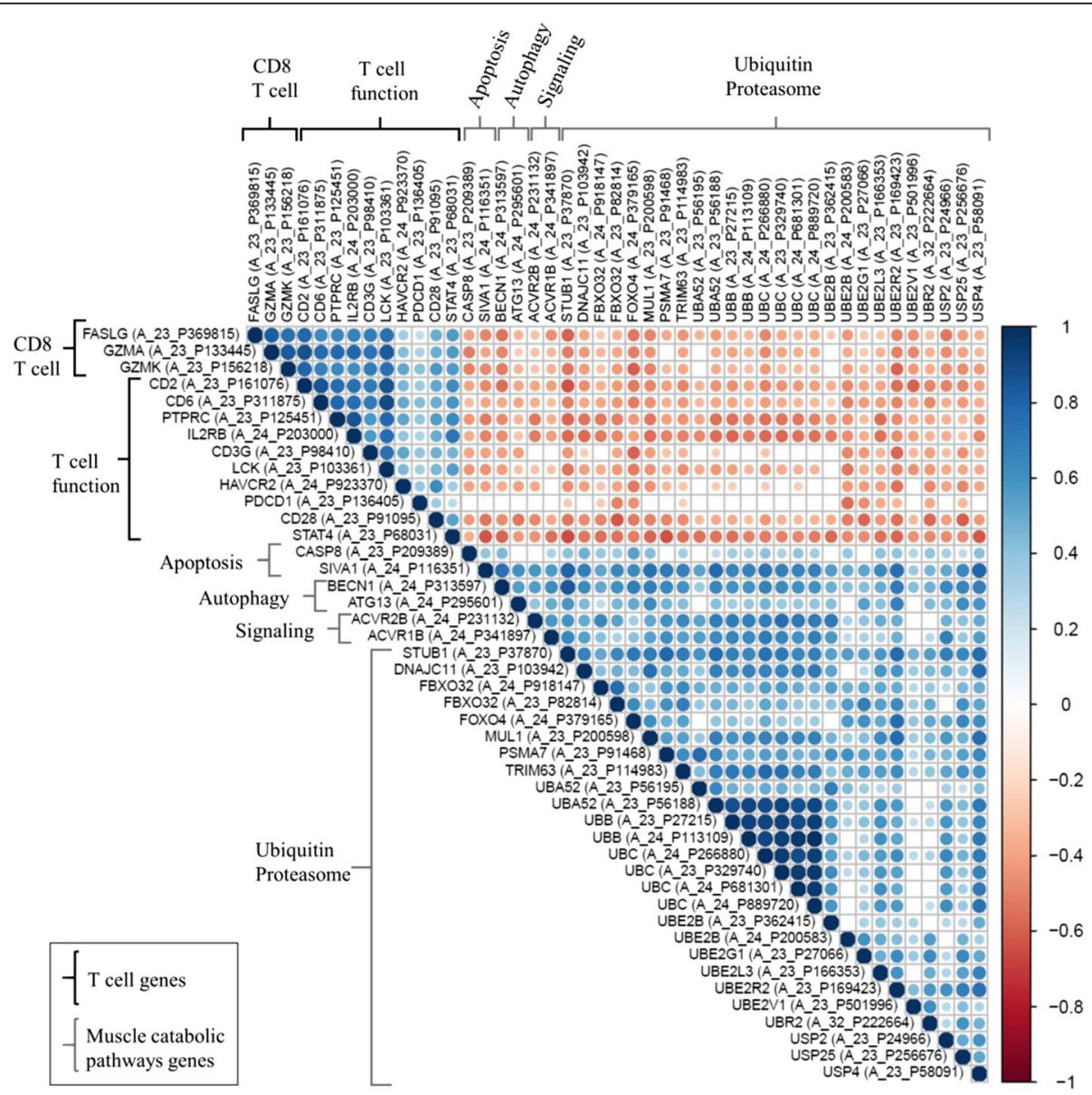

Fig. 4 Correlation matrix of T cells genes and muscle catabolic pathway genes. The strength of the correlation is represented by the size and color intensity of each spot, positive in blue and negative in red. Pearson's correlation analysis. Gene arrays from the rectus abdominis muscle from the secondary male cohort $(n=69)$ 
cell numbers and muscle mass revealed a greater number of $\mathrm{T}$ cells (CD3+), granulocyte/phagocytes $(\mathrm{CD} 11 \mathrm{~b}+\mathrm{CD} 14+\mathrm{CD} 15+)$ and CD3-CD4+ cells in patients with larger muscle fiber size. In particular, CD3+CD4- cells, profiled as CD8 T cells by exclusion, were positively correlated with both histological and radiological indices of muscle mass. In support of this finding, CD8 (CD3+CD4-) T cell-associated genes were negatively correlated with genes involved in muscle catabolic pathways.

In cancer preclinical models, mobilization of immune cells participating in innate and adaptive responses has been observed in several tissues and organs (i.e., blood, brain, liver, adipose tissue) [39]. It is suggested that immune mediators originating in the tumor micro-environment could influence the rearrangement of the immune environment of the skeletal muscle influencing muscle mass (Fig. 5) [40-44]. In humans, linear relationships between blood immune cell counts, used as markers for systemic inflammation, and radiological assessments of muscle mass have been reported [45-51]. Similar to our CD3+ $\mathrm{T}$ cell findings, peripheral lymphocyte counts, which include $\mathrm{T}$ cells and other adaptive responders, have been positively associated with higher SMI in gastrointestinal and lung cancers [48-53]. Elevated levels of circulating granulocytes, in particular, neutrophils, are consistently reported in cancer patients with low muscle mass [54-57], which is contrary to our results from CD11b+ phagocyte/granulocyte cells. Importantly, this finding could be explained by the relationship between granulocytes and $\mathrm{T}$ cells, where cancer patients with low circulatory neutrophil-lymphocyte ratios (NLR) seem to have higher SMI compared to those with elevated NLR. For more individual markers, dendritic cells (phagocytes), which can be identified as CD11b+ cells [58], have been found to be elevated in the blood of patients with high SMI [47]. CD3-CD4+ cells, which were positively correlated with muscle fiber CSA, might belong to a subtype of $\mathrm{T}$ cells with a low expression of surface $\mathrm{CD} 3$, or even, CD4+ antigen-presenting cells [58-61]. Collectively, this evidence suggests that immune cells influence muscle mass during cancer.

Consistent associations of CD8 T cells (CD3+CD4-) with histological and radiological indices of muscle mass revealed that low numbers of $\mathrm{CD} 8 \mathrm{~T}$ cells are present in patients with low muscle mass. The associations observed here do not imply causal mechanisms; however, one could speculate on the possibility that CD8 T cells could influence muscle mass. Further exploration on the CD8A gene, suggested an inverse association of CD8 T cells with apoptosis (caspase 8), autophagy (Beclin 1), catabolic signaling (ACVR2B and ACVR1B receptors), and ubiquitin-proteasome (FBXO32, FOXO4, MUL1, and TRIM63) pathways which collectively would result in improvement or maintenance of muscle mass (Fig. 5) $[1,2,62]$. In accordance with our findings, downregulation of the CD8A T cell gene is observed in the blood of patients experiencing loss of muscle mass, when compared to non-losing patients [57]. A pilot study, evaluating several circulating CD8 $\mathrm{T}$ cells subsets (naïve and

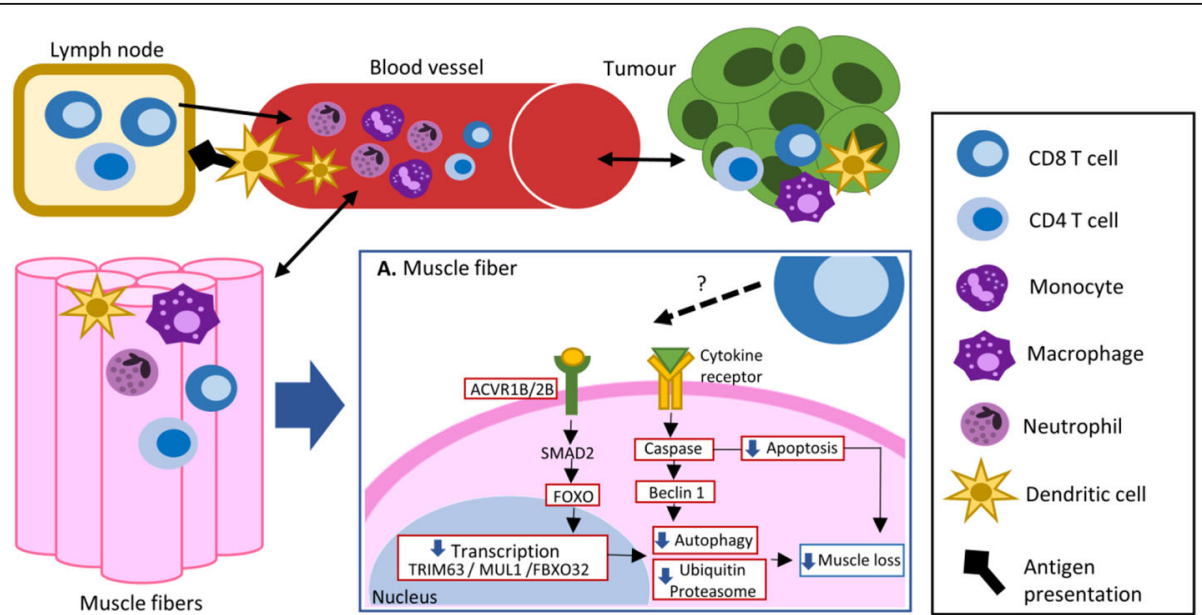

Fig. 5 The presence of immune cells in the skeletal muscle tissue during cancer and the potential role of CD8 T cells in the muscle mass preservation. During cancer, changes in immune cell populations occur. Inflammatory mediators secreted by the tumor are capable of activating and mobilizing circulating and tissue-resident immune cells. The presence of T cells (CD8 and CD4) within the muscle tissue occurs in collaboration of antigen-presenting cells (i.e., dendritic cells) that travel from the tissues into the bloodstream and lymph nodes. Once in the muscle, cytokine secretion by T cells, granulocytes (i.e., neutrophils), and phagocytes (i.e., macrophages and dendritic cells) promote further recruitment and phenotype polarization (inflammatory or anti-inflammatory) of immune cells. A. Close-up of the muscle fiber and nucleus. Gene correlation analysis suggests an inverse relationship of CD8 T cells with diverse components (in red boxes) of muscle catabolic pathways which might impact muscle mass 
memory/pro-inflammatory and anti-inflammatory) in a population with mainly gastrointestinal malignancies, provided a more complex perspective on the relationships between CD8 $\mathrm{T}$ cell subsets and lean mass, where pro-inflammatory CD8 $\mathrm{T}$ cells (expressing IL-2) were negatively associated with lean mass while other phenotypes were not associated [63].

Cross-talk between muscle and immune cells is essential to restore homeostasis and promote muscle tissue repair after a catabolic event [40]. For instance, positive correlation of CD8A gene with IL-10 receptor suggests an involvement of CD8 T cells $[64,65]$ and other antiinflammatory immune cells (M2 macrophages) $[66,67]$ in the IL-10 pathway of the skeletal muscle which involves a reduction in the expression of pro-inflammatory mediators (IL-6, IL- $1 \alpha$, IL- $\beta$, TNF- $\alpha$, and IFN- $\gamma$ ) leading to the support of anabolic hormones activity and regulation of myogenesis [67-69].

Comparison of our quantifications and observations suggest that muscle immune environment from cancer patients might differ from both healthy and inflammatory muscle disease (Table 5). We did not observe characteristics of inflammatory myopathy such as immune cell clusters, muscle fiber infiltration, and perifascicular atrophy [70]. Cautious comparisons with immune cell quantifications done in other muscle groups inform that higher and variable numbers of $\mathrm{T}$ cells are present in patients with muscle inflammatory disease when compared to the present cancer population $[7,11,12]$. In addition, $\mathrm{T}$ cells and granulocyte/phagocytes $(\mathrm{CD} 11 \mathrm{~b}+)$ are scarce in healthy individuals in comparison to people with cancer or inflammatory myopathy $[7,12]$.

The main scientific approach of this study was based on inter-individual variations across the range of muscle mass in cancer patients. We biopsied a representative sample of patients (Fig. 1) across the entire SMI distribution reported for patients with cancers in our geographical region, and our study did not have sampling bias issues [13]. In this distribution, some patients have muscle mass comparable to the normal range expected for healthy 30-year-old individuals [20], and others have significant muscle depletion (Fig. 1 and Table 4). We acknowledge the limitations of our current cohort, which is not completely clear how the effect of advanced cancer stage or chemotherapy exposure is accounted for. It is recognized that advanced cancer is associated with intense catabolism which influences muscle mass and immune cells [71-73]; however, patients with advanced cancer, which were located among the whole SMI distribution in our study, can experience periods of muscle mass maintenance during their disease trajectory [74]. For those patients exposed to chemotherapy prior to biopsy, again found along the SMI distribution with the exception of patients with greater muscle mass, chemotherapeutic agents promote cytotoxicity and metabolic alterations [75-77]; however, long-term effects of muscle immune environment have not been extensively explored.

Whether the muscles of cancer patients are different from those of healthy controls is a legitimate question; however, the feasibility of obtaining the rectus abdominis from appropriately matched healthy controls is questionable. This would be limited to healthy persons having elective abdominal surgery and CT imaging for quantification of muscle mass (a relatively infrequent event). The control population would also need to be proven free of any acute or chronic conditions associated with muscle wasting. As a consequence, a very small number of studies include healthy controls [13].

Our study confirms the presence of immune cells within the muscle of cancer patients; further exploration of immune cell phenotypes (i.e., more detailed analysis of maturation and activation) and immune mediators (e.g., cytokines) is necessary to better understand the local immune cell environment in relation to the muscle mass in cancer. Evaluation of changes in immune cells, muscle mass, and disease progression over time will expand on the findings of the current research which is limited by its cross-sectional design.

Table 5 Human studies reporting number of CD3+ (T cells) and CD11b+ (granulocytes/phagocytes) in muscle

\begin{tabular}{|c|c|c|c|c|c|c|}
\hline Study & Subjects & $\begin{array}{l}\text { Age } \\
\text { (years) }\end{array}$ & $\begin{array}{l}\text { Sample } \\
\text { size }\end{array}$ & $\begin{array}{l}\text { Muscle } \\
\text { group }\end{array}$ & $\begin{array}{l}\text { Number of } \\
\mathrm{CD} 3+/ \mathrm{mm}^{2}\end{array}$ & $\begin{array}{l}\text { Number of } \\
\text { CD11b+/mm }\end{array}$ \\
\hline $\begin{array}{l}\text { Anoveros-Barrera et al. } \\
\text { (current study) }\end{array}$ & $\begin{array}{l}\text { Cancer population, } \\
\text { men and women }\end{array}$ & $64(38-81)$ & $n=30$ & rectus abdominis & $12.3(1.6-33.3)$ & $3(0-13)$ \\
\hline Pandya et al. [11] & Myopathy, men and women & $64(43-74)$ & $n=16$ & VA and TA & $13.5(0.5-963)$ & N/A \\
\hline \multirow[t]{2}{*}{ Dorph et al. [12] } & Myopathy, men and women & $58(38-76)$ & $n=11$ & VA and TA & $\begin{array}{l}\text { Symptomatic muscles: } 58.1 \\
\text { (0.5-159.8) } \\
\text { Asymptomatic muscles: } 55.9 \\
(1.1-126.8)\end{array}$ & N/A \\
\hline & Healthy volunteers, men and women & $51(47-56)$ & $n=6$ & $\mathrm{VL}$ and $\mathrm{TA}$ & $1.8(0.4-5.0)$ & \\
\hline \multirow[t]{2}{*}{ Englund et al. [7] } & Myopathy, men and women. & $46(26-64)$ & $n=11$ & $V L$ & $3(0-7)$ & $1(0-10)$ \\
\hline & Healthy volunteers, men and women & $27(22-46)$ & $n=7$ & $\mathrm{VL}$ & $1(0-2)$ & $0(0-1)$ \\
\hline
\end{tabular}

Values reported as median (minimum-maximum). Myopathy: polymyositis and dermatomyositis. VL vastus lateralis, TA tibialis anterior, N/A not assessed 


\section{Conclusion}

This is the first study to investigate the local immune environment of the skeletal muscle by identifying immune cell populations in the muscle and their relationship to muscle mass in cancer patients. The skeletal muscle immune environment of patients with cancer is comprised of different immune cells from the adaptive and innate immune response. The muscle tissue immune environment in cancer patients might differ from healthy conditions and muscle inflammatory disease. Correlations of $\mathrm{T}$ cells, granulocyte/phagocytes, and CD3-CD4+ cells with histological and radiological muscle mass measurements suggest a relationship between immune cells and muscle mass status. Gene correlation analysis suggests an inverse relationship of CD8 $\mathrm{T}$ cells with diverse components of muscle catabolic pathways which might have an impact on muscle mass preservation during cancer. These results serve to better understand the role of the local immune environment of skeletal muscle and its implications for muscle mass in cancer patients.

\section{Additional files}

Additional file 1: Table S1. Primary antibody panel for
immunohistochemistry. (DOCX $21 \mathrm{~kb}$ )

Additional file 2: Table S2. Secondary antibody panel for immunohistochemistry with corresponding primary antibodies. (DOCX 20 kb)

Additional file 3: Table S3. Patient characteristics, secondary cohort with microarray analysis in rectus abdominis muscle. (DOCX $23 \mathrm{~kb}$ )

Additional file 4: Table S4. Negative univariate associations $(r=<-0.50)$ between $T$ cell related genes and genes involved in muscle catabolic pathways of rectus abdominis muscle of secondary male cohort $(n=69)$. (DOCX $27 \mathrm{~kb}$ )

Additional file 5: Table S5. Negative univariate associations between T cell related genes and genes involved in muscle catabolic pathways of rectus abdominis muscle of secondary female cohort $(n=64)$. (DOCX $25 \mathrm{~kb}$ )

Additional file 6: Figure S1. Immunostaining of $C D 3+C D 4+(A)$, CD3+CD4- (B), CD3-CD4+ (C), CD11b+CD14-CD15- (D) and

$\mathrm{CD} 11 \mathrm{~b}+\mathrm{CD} 14+\mathrm{CD} 15+(\mathrm{E})$ cells. Immune cells pointed by the white arrow. A.1, B.1, C.1, D.1 and E.1 antibody detected by Alexa Flour ${ }^{\oplus}$ 647. A.2, B.2, C.2, D.2 and E.2 antibody detected by Alexa Flour ${ }^{\oplus}$ 568. D.3 and E.3 antibody detected by Alexa Flour ${ }^{\oplus}$ 488. A.3, B.3, C.3, D.4 and E.4 nuclear stain detected by DAPI. A.4. B.4, C.4, D.5 and E.5 Merged images. Scale bar $45 \mu \mathrm{m}$. (DOCX 1768 kb)

Additional file 7: Figure S2. Immunostaining of serial cross-sections of muscle tissue: CD11b+CD14+CD15+ cells (A) and laminindystrophin (B). Stained nuclei in blue. A.1 Original image with no brightness manipulation. A.2 and A.3 Brightness was increased to visually appreciate the location of the CD11b+CD14+CD15+ cell (arrow) on the endomysial area. B. Serial cross-section used to confirm the location of immune cells on the periphery of muscle fibers (endomysium). Asterisks mark muscle fibers used as a reference point, and immune cell location is pointed by the white arrow. Scale bar $11 \mu \mathrm{m}$. (DOCX $1549 \mathrm{~kb}$ )

Additional file 8: Figure S3. Flow cytometry analyses done using FlowJo@ software [FlowJo, LLC]. A. Gating strategy for the main cell population. B. Exclusion of doublets. C and F. Gating strategy for CD3 and CD11b positive populations. D and G. Stable flow stream for CD3 and CD11b. E and H. FMO controls for CD3 and CD11b. (PDF $443 \mathrm{~kb}$ )
Additional file 9: Figure S4. Gene arrays from rectus abdominis muscle from secondary female cohort $(n=64)$. Correlation matrix of $T$ cells genes and muscle catabolic pathway genes. Strength of the correlation is represented by the size and color intensity of each spot, positive in blue and negative in red. Pearson correlation analysis. (DOCX $1449 \mathrm{~kb}$ )

\section{Abbreviations}

CSA: Cross-sectional area; CT: Computed tomography; HU: Hounsfield units; IL: Interleukin; L3: Lumbar 3; NFKB: Nuclear factor kappa-B; NLR: Neutrophil lymphocyte ratio; SMI: Skeletal muscle index; TNF: Tumor necrosis factor

\section{Acknowledgements}

Images for immunofluorescence experiments were conducted at the Cell Imaging Center, University of Alberta, Edmonton, Alberta, Canada.

\section{Authors' contributions}

AA contributed to the conceptualization, design, analysis, writing, and interpretation. AB contributed to the conceptualization, design, experimental optimization, and tissue processing. CS contributed to the gene array data analysis, interpretation, and creation of Fig. 4 and Additional file 4: Table S4. ARD contributed to the $C T$ image analysis and experimental optimization. KJBM contributed to the experimental optimization and immunohistochemistry image analysis. AR was involved in the flow cytometry experimental design and data analysis. DB, TM, and OFB contributed to the patient recruitment, biopsy, and clinical data collection. CTP contributed to the interpretation and editing. CJF was involved in the experimental design, data interpretation, and manuscript development. VCM and VEB contributed to the conceptualization, design, analysis, interpretation, and editing. All authors of this research paper commented on the initial drafts and have approved the final version.

\section{Funding}

Funding for this project is from the Canadian Institutes of Health Research $(\mathrm{CIHR})$ operating grants awarded to Vera Mazurak. Ana Anoveros-Barrera is a recipient of the Doctoral Fellowship from the Consejo Nacional de Ciencia y Tecnología (CONACyT) of Mexico (428279). Amritpal Bhullar is the holder of the Alberta Innovates Technology Futures (AITF) award at University of Alberta, Canada. Aja Rieger is an ISAC SRL Emerging Leader (2017-2022).

\section{Availability of data and materials}

Data for main cancer patient cohort $(n=30)$ is available upon request. Data for microarray cohort $(n=69)$ is deposited in the US National Center for Biotechnology Information (NCBI) Gene Expression Omnibus25. GEO series accession number GSE41726.

\section{Ethics approval and consent to participate}

Written consent for participation in the present study was obtained from all patients previous to intraoperative collection of muscle biopsy. This study was approved by the Health Research Ethics Board of Alberta-Cancer Committee; all patients provided informed consent previous to the surgery. Procedures were performed from July 2015 to July 2017 at the University of Alberta Hospital, Edmonton, Canada, under the protocol ETH-21709: The Molecular Profile of Cancer Cachexia.

\section{Consent for publication}

Not applicable.

\section{Competing interests}

The authors declare that they have no competing interests.

\section{Author details}

${ }^{1}$ Department of Agricultural, Food \& Nutritional Science, Faculty of Agricultural, Life and Environmental Sciences, University of Alberta, 4-002 Li Ka Shing Centre, Edmonton, Alberta T6G 2P5, Canada. ${ }^{2}$ Department of Oncology, University of Calgary, Calgary, Alberta, Canada. ${ }^{3}$ Flow Cytometry Facility, Faculty of Medicine and Dentistry, University of Alberta, Edmonton, Alberta, Canada. ${ }^{4}$ Department of Surgery, Faculty of Medicine and Dentistry, University of Alberta, Edmonton, Alberta, Canada. ${ }^{5}$ Department of Oncology and Department of Surgery, University of Calgary, Calgary, Alberta, Canada. ${ }^{6}$ Faculty of Kinesiology, Sport, and Recreation, Faculty of Medicine and 
Dentistry, University of Alberta, Edmonton, Alberta, Canada. ${ }^{7}$ Department of Oncology, Faculty of Medicine and Dentistry, University of Alberta, Edmonton, Alberta, Canada.

\section{Received: 18 April 2019 Accepted: 16 August 2019} Published online: 14 September 2019

\section{References}

1. Baracos VE, Martin L, Korc M, Guttridge DC, Fearon KCH. Cancer-associated cachexia. Nat Rev Dis Prim. 2018;4:17105

2. Egerman MA, Glass DJ. Signaling pathways controlling skeletal muscle mass, Crit Rev Biochem Mol Biol. 2014;49:59-68.

3. De Alvaro C, Teruel T, Hernandez R, Lorenzo M. Tumor necrosis factor a produces insulin resistance in skeletal muscle by activation of inhibitor $\mathrm{KB}$ kinase in a p38 MAPK-dependent manner. J Biol Chem. 2004;279:17070-8.

4. Hohlfeld R, Engel AG. Coculture with autologous myotubes of cytotoxic $T$ cells isolated from muscle in inflammatory myopathies. Ann Neurol. 1991;29:498-507.

5. Pandya JM, Venalis $P$, Al-Khalili L, Shahadat Hossain M, Stache $V$, Lundberg IE, et al. CD4+ and CD8+ CD28nullT cells are cytotoxic to autologous muscle cells in patients with polymyositis. Arthritis Rheumatol. 2016:68:2016-26.

6. Zampieri S, Valente M, Adami N, Biral D, Ghirardello A, Rampudda ME, et al. Polymyositis, dermatomyositis and malignancy: a further intriguing link. Autoimmun Rev. 2010;9:449-53.

7. Englund P, Nennesmo I, Klareskog L, Lundberg IE. Interleukin-1a expression in capillaries and major histocompatibility complex class I expression in type II muscle fibers from polymyositis and dermatomyositis patients: important pathogenic features independent of inflammatory cell clusters in muscle tis. Arthritis Rheum. 2002;46:1044-55.

8. Malm C, Nyberg P, Engstrom M, Sjodin B, Lenkei R, Ekblom B, et al. Immunological changes in human skeletal muscle and blood after eccentric exercise and multiple biopsies. J Physiol. 2000:529(Pt 1):243-62.

9. Malm C, Sjödin B, Sjöberg B, Lenkei R, Renström P, Lundberg IE, et al. Leukocytes, cytokines, growth factors and hormones in human skeletal muscle and blood after uphill or downhill running. J Physiol. 2004:556:983-1000.

10. Bruun JM, Helge JW, Richelsen B, Stallknecht B, Bruun JM. Diet and exercise reduce low-grade inflammation and macrophage infiltration in adipose tissue but not in skeletal muscle in severely obese subjects. Am J Physio Endocrinol Metab. 2006;290:961-7.

11. Pandya JM, Loell I, Hossain MS, Zong M, Alexanderson H, Raghavan S, et al. Effects of conventional immunosuppressive treatment on CD244+ (CD28null) and FOXP3+ T cells in the inflamed muscle of patients with polymyositis and dermatomyositis. Arthritis Res Ther. 2016;18:1-14.

12. Dorph C, Englund P, Nennesmo I, Lundberg IE. Signs of inflammation in both symptomatic and asymptomatic muscles from patients with polymyositis and dermatomyositis. Ann Rheum Dis. 2006:65:1565-71.

13. Anoveros-Barrera A, Bhullar AS, Stretch C, Esfandiari N, Dunichand-hoedl AR, Karen JB, et al. Clinical and biological characterization of skeletal muscle tissue biopsies of surgical cancer patients. J Cachexia Sarcopenia Muscle. 2019; jcsm. 12466.

14. Narasimhan A, Ghosh S, Stretch C, Greiner R, Bathe OF, Baracos V, et al. Small RNAome profiling from human skeletal muscle: novel miRNAs and their targets associated with cancer cachexia. J Cachexia Sarcopenia Muscle. 2017:8:405-16

15. Narasimhan A, Greiner R, Bathe OF, Baracos V, Damaraju S. Differentially expressed alternatively spliced genes in skeletal muscle from cancer patients with cachexia. J Cachexia Sarcopenia Muscle. 2018:9:60-70.

16. Prado CMM, Lieffers JR, McCargar $L$, Reiman T, Sawyer MB, Martin L, et al. Prevalence and clinical implications of sarcopenic obesity in patients with solid tumours of the respiratory and gastrointestinal tracts: a populationbased study. Lancet Oncol. 2008;9:629-35.

17. Mourtzakis M, Prado CMM, Lieffers JR, Reiman T, McCargar LJ, Baracos VE. A practical and precise approach to quantification of body composition in cancer patients using computed tomography images acquired during routine care. Appl Physiol Nutr Metab. 2008;33:997-1006.

18. Martin L, Birdsell L, MacDonald N, Reiman T, Clandinin MT, McCargar LJ, et al. Cancer cachexia in the age of obesity: skeletal muscle depletion is a powerful prognostic factor, independent of body mass index. J Clin Oncol. 2013;31:1539-47.
19. Kazemi-Bajestani SMR, Mazurak VC, Baracos V. Computed tomographydefined muscle and fat wasting are associated with cancer clinical outcomes. Semin Cell Dev Biol. 2016;54:2-10.

20. Derstine BA, Holcombe SA, Ross BE, Wang NC, Su GL, Wang SC. Skeletal muscle cutoff values for sarcopenia diagnosis using T10 to $L 5$ measurements in a healthy US population. Sci Rep. 2018;8:11369.

21. Mckay BR, Toth KG, Tarnopolsky MA, Parise G. Satellite cell number and cell cycle kinetics in response to acute myotrauma in humans: immunohistochemistry versus flow cytometry. J Physiol. 2010;17:3307-20.

22. Stretch C, Khan S, Asgarian N, Eisner R, Vaisipour S, Damaraju S, et al. Effects of sample size on differential gene expression, rank order and prediction accuracy of a gene signature. PLoS One. 2013;8:1-6.

23. Weng N, Araki Y, Subedi K. The molecular basis of the memory T cell response: differential gene expression and its epigenetic regulation. Nat Rev Immunol. 2012;12:306-15.

24. Lyons YA, Wu SY, Overwijk WW, Baggerly KA, Sood AK. Immune cell profiling in cancer: molecular approaches to cell-specific identification. npj Precis Oncol. 2017;1:26.

25. Stoeckle C, Gouttefangeas C, Hammer M, Weber E, Melms A, Tolosa E. Cathepsin W expressed exclusively in CD8+ T cells and NK cells is secreted during target cell killing but is not essential for cytotoxicity in human CTLS. Exp Hematol. 2009;37:266-75.

26. Mueller SN, Gebhardt T, Carbone FR, Heath WR. Memory T cell subsets, migration patterns, and tissue residence. Annu Rev Immunol. 2013;31:137-61.

27. Kaech SM, Hemby S, Kersh E, Ahmed R. Molecular and functional profiling of memory CD8 T cell differentiation. Cell. 2002;111:837-51.

28. Crespo J, Sun H, Welling TH, Tian Z, Zou W. T cell anergy, exhaustion, senescence, and stemness in the tumor microenvironment. Curr Opin Immunol. 2013;25:214-21.

29. Barreto R, Kitase $Y$, Matsumoto T, Pin F, Colston KC, Couch KE, et al. ACVR2B/Fc counteracts chemotherapy-induced loss of muscle and bone mass. Sci Rep. 2017;7:14470.

30. Marchildon F, Fu D, Lala-Tabbert N, Wiper-Bergeron N. CCAAT/enhancer binding protein beta protects muscle satellite cells from apoptosis after injury and in cancer cachexia. Cell Death Dis. 2016;7:e2109.

31. Argilés JM, Busquets S, Stemmler B, López-Soriano FJ. Cancer cachexia: understanding the molecular basis. Nat Rev Cancer. 2014;14:754-62.

32. Johns N, Stretch C, Tan BHL, Solheim TS, Sørhaug S, Stephens NA, et al. New genetic signatures associated with cancer cachexia as defined by low skeletal muscle index and weight loss. J Cachexia Sarcopenia Muscle. 2017;8:122-30.

33. Silva KAS, Dong J, Dong Y, Dong Y, Schor N, Tweardy DJ, et al. Inhibition of Stat3 activation suppresses caspase-3 and the ubiquitin-proteasome system, leading to preservation of muscle mass in cancer cachexia. J Biol Chem. 2015;290:11177-87.

34. Milan G, Romanello V, Pescatore F, Armani A, Paik J-H, Frasson L, et al. Regulation of autophagy and the ubiquitin-proteasome system by the FoxO transcriptional network during muscle atrophy. Nat Commun. 2015;6:6670.

35. Fan J, Yang X, Li J, Shu Z, Dai J, Liu X, et al. Spermidine coupled with exercise rescues skeletal muscle atrophy from D-gal-induced aging rats through enhanced autophagy and reduced apoptosis via AMPK-FOXO3a signal pathway. Oncotarget. 2017:8:17475-90.

36. Sánchez-Espiridión B, Martin-Moreno AM, Montalbán C, Jeffrey Medeiros L, Vega F, Younes A, et al. Immunohistochemical markers for tumor associated macrophages and survival in advanced classical Hodgkin's lymphoma. Haematologica. 2012;97:1080-4.

37. Cottle DL, McGrath MJ, Wilding BR, Cowling BS, Kane JM, D'Arcy CE, et al. SLIMMER (FHL1B/KyoT3) interacts with the proapoptotic protein Siva-1 (CD27BP) and delays skeletal myoblast apoptosis. J Biol Chem. 2009:284:26964-77.

38. Belizário JE, Lorite MJ, Tisdale MJ. Cleavage of caspases-1, -3, -6, -8 and -9 substrates by proteases in skeletal muscles from mice undergoing cancer cachexia. Br J Cancer. 2001;84:1135-40.

39. Burfeind KG, Zhu X, Norgard MA, Levasseur PR, Olson B, Michaelis KA, et al. A distinct neutrophil population invades the central nervous system during pancreatic cancer. bioRxiv. 2019:659060.

40. Tidball JG. Regulation of muscle growth and regeneration by the immune system. Nat Rev Immunol. 2017;17:165-78.

41. Madaro L, Bouché M. From innate to adaptive immune response in muscular dystrophies and skeletal muscle regeneration: the role of lymphocytes. Biomed Res Int. 2014;2014:1-12. 
42. Burfeind KG, Zhu X, Levasseur PR, Michaelis KA, Norgard MA, Marks DL. TRIF is a key inflammatory mediator of acute sickness behavior and cancer cachexia. Brain Behav Immun. 2018;73:364-74.

43. Zhang G, Liu Z, Ding H, Miao H, Garcia JM, Li YP. Toll-like receptor 4 mediates Lewis lung carcinoma-induced muscle wasting via coordinate activation of protein degradation pathways. Sci Rep. 2017;7:1-8.

44. Cannon TY, Guttridge D, Dahlman J, George JR, Lai V, Shores C, et al. The effect of altered toll-like receptor 4 signaling on cancer cachexia. Arch Otolaryngol Neck Surg. 2007;133:1263.

45. Malietzis G, Johns N, Al-Hassi HO, Knight SC, Kennedy RH, Fearon KCH, et al. Low muscularity and myosteatosis is related to the host systemic inflammatory response in patients undergoing surgery for colorectal cancer. Ann Surg. 2016;263:320-5.

46. Go S, Park MJ, Song H, Kang MH, Park HJ, Jeon KN, et al. Sarcopenia and inflammation are independent predictors of survival in male patients newly diagnosed with small cell lung cancer. Support Care Cancer. 2016;24:2075-84.

47. Malietzis $\mathrm{G}$, Lee $\mathrm{GH}$, Al-Hassi HO, Bernardo D, Blakemore AlF, Kennedy RH, et al. Body composition of the host influences dendritic cell phenotype in patients treated for colorectal cancer. Tumor Biol. 2016;37:11359-64.

48. He WZ, Yang QX, Xie JY, Kong PF, Hu WM, Yang L, et al. Association of low skeletal muscle index with increased systematic inflammatory responses and interferon $\mathrm{Y}$-induced protein 10 levels in patients with colon cancer. Cancer Manag Res. 2018;10:2499-507.

49. Lin J, Zhang W, Huang Y, Chen W, Wu R, Chen X, et al. Sarcopenia is associated with the neutrophil/ lymphocyte and platelet/lymphocyte ratios in operable gastric cancer patients: a prospective study. Cancer Manag Res. 2018;10:4935-44.

50. Feng F, Zheng G, Wang Q, Liu S, Liu Z, Xu G, et al. Low lymphocyte count and high monocyte count predicts poor prognosis of gastric cancer. BMC Gastroenterol. 2018;18:148.

51. Kim EY, Kim YS, Seo J-Y, Park I, Ahn HK, Jeong YM, et al. The relationship between sarcopenia and systemic inflammatory response for cancer cachexia in small cell lung cancer. PLoS One. 2016;11:e0161125.

52. Zheng ZF, Lu J, Xie JW, Wang JB, Lin JX, Chen QY, et al. Preoperative skeletal muscle index vs the controlling nutritional status score: which is a better objective predictor of long-term survival for gastric cancer patients after radical gastrectomy? Cancer Med. 2018;7:3537-47.

53. Baumann K. Integrin's new partner. Nat Rev Mol Cell Biol. 2010;11:164.

54. Black D, Mackay C, Ramsay G, Hamoodi Z, Nanthakumaran S, Park KGM, et al. Prognostic value of computed tomography: measured parameters of body composition in primary operable gastrointestinal cancers. Ann Surg Oncol. 2017;24:2241-51.

55. McSorley ST, Black DH, Horgan PG, McMillan DC. The relationship between tumour stage, systemic inflammation, body composition and survival in patients with colorectal cancer. Clin Nutr. 2018;37:1279-85.

56. Cho Y, Kim JW, Keum KC, Lee CG, Jeung HC, Lee IJ. Prognostic significance of sarcopenia with inflammation in patients with head and neck cancer who underwent definitive chemoradiotherapy. Front Oncol. 2018;8:457.

57. Penafuerte CA, Gagnon B, Sirois J, Murphy J, MacDonald N, Tremblay ML. Identification of neutrophil-derived proteases and angiotensin II as biomarkers of cancer cachexia. Br J Cancer. 2016;114:680-7.

58. Merad M, Sathe P, Helft J, Miller J, Mortha A. The dendritic cell lineage: ontogeny and function of dendritic cells and their subsets in the steady state and the inflamed setting. Annu Rev Immunol. 2013;31:563-604.

59. Esashi E, Ito H, Ishihara K, Hirano T, Koyasu S, Miyajima A. Development of CD4 + macrophages from intrathymic $T$ cell progenitors is induced by thymic epithelial cells. J Immunol. 2004;173:4360-7.

60. Bekiaris V, Sedy JR, Rossetti M, Spreafico R, Sharma S, Rhode-Kurnow A, et al. Human CD4+CD3- innate-like T cells provide a source of TNF and lymphotoxin- and are elevated in rheumatoid arthritis. J Immunol. 2013;191:4611-8.

61. Ravoet M, Sibille C, Gu C, Libin M, Haibe-Kains B, Sotiriou C, et al. Molecular profiling of CD3-CD4+T cells from patients with the lymphocytic variant of hypereosinophilic syndrome reveals targeting of growth control pathways. Blood. 2009;114:2969-83.

62. Wing SS. Deubiquitinating enzymes in skeletal muscle atrophy-an essential role for USP19. Int J Biochem Cell Biol. 2016;79:462-8.

63. Narsale A, Moya R, Ma J, Anderson LJ, Wu D, Garcia JM, et al. Cancer-driven changes link T cell frequency to muscle strength in people with cancer: a pilot study. J Cachexia Sarcopenia Muscle. 2019; jcsm.12424.

64. Liu J, Chen D, Nie GD, Dai Z. CD8(+)CD122(+) T-cells: a newly emerging regulator with central memory cell phenotypes. Front Immunol. 2015;6:494.
65. Endharti AT, Rifá M, Shi Z, Fukuoka Y, Nakahara Y, Kawamoto Y, et al. Cutting edge: CD8+CD122+ regulatory T cells produce IL-10 to suppress IFN-Y production and proliferation of CD8+ T cells. J Immunol. 2005;175:7093-7.

66. Dennis KL, Blatner NR, Gounari F, Khazaie K. Current status of interleukin-10 and regulatory T-cells in cancer. Curr Opin Oncol. 2013;25:637-45.

67. Deng BB, Wehling-Henricks M, Villalta SA, Wang Y, Tidball JG. IL-10 triggers changes in macrophage phenotype that promote muscle growth and regeneration. J Immunol. 2012;189:3669-80.

68. Dagdeviren S, Jung DY, Lee E, Friedline RH, Noh HL, Kim JH, et al. Altered interleukin-10 signaling in skeletal muscle regulates obesity-mediated inflammation and insulin resistance. Mol Cell Biol. 2016;36:2956-66.

69. Trendelenburg A, Meyer A, Jacobi C, Feige JN, Glass DJ. TAK-1/p38/nNFkB signaling inhibits myoblast differentiation by increasing levels of Activin A Skelet Muscle. 2012;2:3.

70. Dalakas MC. Inflammatory muscle diseases. N Engl J Med. 2015;372:1734-47.

71. Lieffers JR, Mourtzakis M, Hall KD, Mccargar L, Prado CMM, Baracos VE. A viscerally driven cachexia syndrome in patients with advanced colorectal cancer: contributions of organ and tumor mass to whole-body energy demands. 2009:89(4):1173-1179.

72. Shibata M, Takekawa M, Amano S. Increased serum concentrations of soluble tumor necrosis factor receptor I in noncachectic and cachectic patients with advanced gastric and colorectal cancer. Surg Today. 1998;28:884-8.

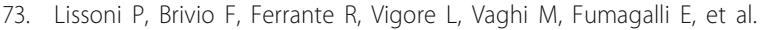
Circulating immature and mature dendritic cells in relation to lymphocyte subsets in patients with gastrointestinal tract cancer. Int Biol Markers. 2000;15:22-5.

74. Prado CM, Sawyer MB, Ghosh S, Lieffers JR, Esfandiari N, Antoun S, et al. Central tenet of cancer cachexia therapy: do patients with advanced cancer have exploitable anabolic potential? Am J Clin Nutr. 2013;98:1012-9.

75. Schiessel DL, Baracos VE. Barriers to cancer nutrition therapy: excess catabolism of muscle and adipose tissues induced by tumour products and chemotherapy. Proc Nutr Soc. 2018;77(4):394-402.

76. Crouch M-L, Knowels G, Stuppard R, Ericson NG, Bielas JH, Marcinek DJ, et al. Cyclophosphamide leads to persistent deficits in physical performance and in vivo mitochondria function in a mouse model of chemotherapy late effects. 2017;12(7)

77. Cooper AB, Slack R, Fogelman D, Holmes HM, Petzel M, Parker N, et al. Characterization of anthropometric changes that occur during neoadjuvant therapy for potentially resectable pancreatic cancer. Ann Surg Oncol. 2015;22:2416-23.

\section{Publisher's Note}

Springer Nature remains neutral with regard to jurisdictional claims in published maps and institutional affiliations.

Ready to submit your research? Choose BMC and benefit from

- fast, convenient online submission

- thorough peer review by experienced researchers in your field

- rapid publication on acceptance

- support for research data, including large and complex data types

- gold Open Access which fosters wider collaboration and increased citations

- maximum visibility for your research: over $100 \mathrm{M}$ website views per year

At BMC, research is always in progress.

Learn more biomedcentral.com/submissions 